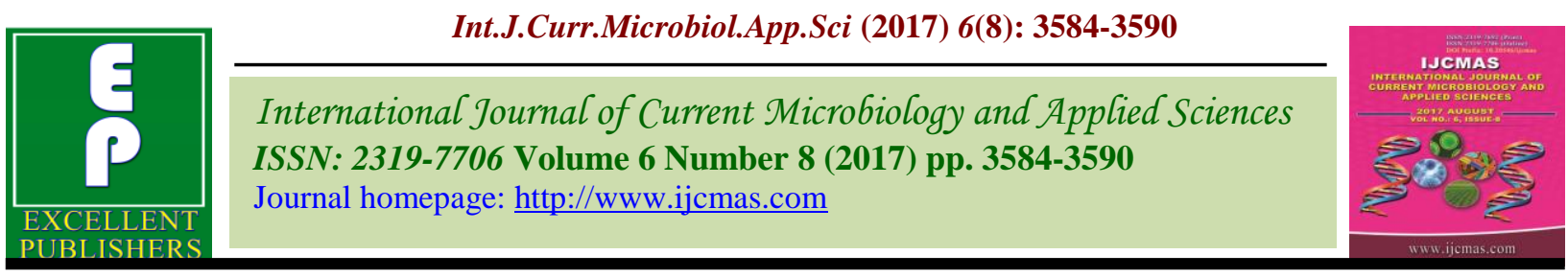

Original Research Article

https://doi.org/10.20546/ijcmas.2017.608.430

\title{
Isolation and Identification of Bacteria from under Fingernails
}

\author{
Mohsen Hashim Risan* \\ College of Biotechnology/Al-Nahrain University, Baghdad, Iraq \\ *Corresponding author
}

\section{A B S T R A C T}

This study was conducted to isolate and identify bacteria contaminants of under nails (long nails). The samples were collected randomly from 20 samples under nails (belonging to volunteers for sampling). This study was conducted between October to December, 2016

\section{Keywords}

Bacteria,

Contaminants, Under nails.

Article Info

Accepted:

27 June 2017

Available Online:

10 August 2017 at College of Biotechnology, Al-Nahrain University. The isolated colonies were then sub cultured in nutrient agar and slants in order to obtain pure culture of all colonies. All students $(100 \%)$ found to harbour bacteria on their under nails. Bacterial pathogens isolated from the under nails of students include Staphylococcus aureus (5 isolates), Bacillus cereus (2 isolates), Acinetobacter spp (1 isolates), Bacillus spp (7 isolates), Streptococcus spp (1 isolates), Pseudomonas aeruginosa (6 isolates), Klebsiella spp (2 isolates) and Unknown (2 isolates). Highest contamination of Bacillus spp was isolated. Showed Percentage of bacterial isolates from the samples collected from under nails after calculating the total percentage of each isolate Staphylococcus aureus $19.23 \%$, Bacillus cereus $7.69 \%$, Acinetobacter spp $3.84 \%$, Bacillus spp $26.92 \%$, Streptococcus spp $3.84 \%$, Pseudomonas aeruginosa $23.07 \%$, Klebsiella spp $7.69 \%$ and Unknown $7.69 \%$. The highest prevalence were in male were (16 isolates) and were percentage of bacteria isolated $61.53 \%$ while in female were (10 isolates) and percentage of bacteria isolated $38.46 \%$. Also showed results Percentage of total bacteria isolated of female and male, were $38.46 \%$ and $61.53 \%$ respectively.

\section{Introduction}

Foodborne diseases are known to contribute to both human morbidity and mortality as well as health care costs. Besides outbreaks of foodborne disease, health care costs associated with these outbreaks are enormous (Bean et al., 1996; Campbell et al., 1998). The human body surface is constantly in contact with environmental microorganisms and become readily colonized by certain microbial species, Gram-negative and Grampositive pathogens in clinical specimens. It can cause a variety of community- or hospital-acquired infections, including those of the urinary tract, respiratory tract, wounds and burns, bacteriaemia, neonatal meningoencephalitis, empyema and osteomyelitis. The hand serves as a major vehicle of transmission of various microbes, including the enteric species (Prescott et al., 2005). Various infections via hands and fingernails. Contaminated of hands play a major role in faecal-oral transmission of diseases (Ray et al., 2011). The unhygienic habits of most of the people lead to the various infections via hands and fingernails. $80 \%$ of the diseases are associated with the poor domestic and personal hygiene. One of the ways of healthy living is hand hygiene (Patel et al., 2010). Faecal contamination of hands is one of the important route by which 
children are exposed to pathogenic organisms (Langford, 2009). Wachukwu et al., (2007). Finding that artificial fingernails could serve as means for transmission of pathogens to foods and causing nosocomial infections in patients. Four genera of bacteria were isolated and identified, such as Staphylococcus sp., Escherichia coli, Proteus sp. and Pseudomonas sp. Among the organism identified, Staphylococcus aureus (41.7\%) was predominant and frequently occurring, followed by $E$. coll (7.4\%). Hedderwick et al., (2000) Concluded in a study that artificial fingernails were more likely to harbor pathogens, especially gram-negative bacilli and yeasts, than native nails. Schools and Universities are an ideal environment for the spread of infection and infectious diseases. Transmission of bacterial enteric infections via hands has important consequences for students, as they are more likely to take meal and water without washing hands; therefore they are posed to risk of infection. (Lau et al., 2012). This study was conducted to isolate and identify bacteria, contaminants on under the nails (long nails).

\section{Materials and Methods}

\section{Collection of samples}

A total of 20 swab samples were collected randomly from 20 samples under nails (belonging to volunteers for sampling). This study was conducted between October to December, 2016 at College of Biotechnology, Al-Nahrain University, with sterile cotton swab sticks. Sampling was done using sterile cotton swab sticks. The swab sticks were rubbed all over the surface of under nails. The cotton swabs were transferred immediately to the laboratory with one hour of collection to prevent dryness. The nutrient agar was prepared in $500 \mathrm{ml}$ flask and was sterilized by autoclaving at $121^{\circ} \mathrm{C}$ at 15 psi for 20 minutes. $20 \mathrm{ml}$ of the media was poured in the petri plates before getting solidified. The swab was immediately streaked on three plates of Nutrient agar. The plates were incubated at $37^{\circ} \mathrm{C}$ for 24 hours. The plates were then observed for growth and a colonial description of the isolates. Selected colonies were again sub- cultured on nutrient agar in petri- plates to isolate pure culture. After isolating pure cultures, bacterial isolates were further identified and characterized by size and shape and gram staining of colonies.

\section{Isolation and Identification Methods}

\section{Cultural Methods}

The nutrient agar medium was used in the study for isolation of the bacteria. The detail information was collected based on age and sex during collection under the nails (long nails) samples. The cultures were incubated at $37 \mathrm{C}^{\circ}$ and checked for bacterial growth at 24 hours. Separate colonies were subcultured onto nutrient agar to obtain pure culture. Morphological Characteristics of colonies and gram stain tests and biochemical tests were, according (Ramos, 2004; Ekrakene and Igeleke 2009) that used for bacterial identification.

\section{Identification of bacteria}

Subculture was done from each plate on Nutrient Agar and incubated at $37^{\circ} \mathrm{C}$ for 24 hours. Morphological and biochemical properties of the isolate were identified, evaluated, and compared, according (Ramos, 2004; Ekrakene and Igeleke, 2009).

Several biochemical identification methods such as shape, Gram stain, Indole Test, Oxidase test, Catalase test, Citrate Utilization Test, Urease Test, Coagulase Test and Nitrate reduction test were conducted to identify the isolated bacteria (Holding and Collee, 1971; Abdulkadir and Waliyu, 2012). 


\section{Results and Discussion}

Microbial contamination of the under nails has become a global health problem. Thus a total of 20 under nails swabs from under the nails, in left and right hands of 20 students were collected.

All students (100\%) found to harbour bacteria on their under nails. Bacterial pathogens isolated from the under nails of students. Gram-positive bacteria isolates were Staphylococcus aureus (5 isolates), Bacillus cereus (2 isolates), Bacillus spp (7 isolates) and Streptococcus spp (1 isolates) while Gram negative bacteria were isolated from under nails, Acinetobacter spp (1 isolates), Pseudomonas aeruginosa (6 isolates), Klebsiella spp (2 isolates) and Unknow (2 isolates). Highest contamination of Bacillus spp was isolated. (Table 1).

Showed Percentage of bacterial isolates from the samples collected from under nails after calculating the total percentage of each isolate Staphylococcus aureus 19.23\%, Bacillus cereus $7.69 \%$, Acinetobacter spp 3.84\%, Bacillus spp 26.92\%, Streptococcus spp $3.84 \%$, Pseudomonas aeruginosa $23.07 \%$, Klebsiella spp $7.69 \%$ and Unknow $7.69 \%$ (Figure 1) as the number and types of bacteria associated with the hands are of greater concern for health.
Seven colonies isolated and identified using biochemical tests, colony morphology, and staining properties and sugar fermentation were in (Table 2). Gram negative bacilli, Acinetobacter spp, Pseudomonas aeruginosa, and Klebsiella spp and Gram positive cocci and some bacilli, Streptococcus and Staphylococcus spp., Bacillus and Bacillus cereus. Staining helps in the identification of the organism's morphology and cell arrangement.

Opportunistic pathogens such as bacteria, viruses and fungi can survive on inanimate surfaces for long periods of time and items such as watches, pens, and mobile phones are permanent surfaces for transmission of these types of infections (Akinyemi et al., 2009). Ryan et al., (2004) Explain Pseudomonas spp. are Rugged and opportunistic.

The highest prevalence were in male were (16 isolates) and were percentage of bacteria isolated $61.53 \%$ while in female were (10 isolates) and percentage of bacteria isolated $38.46 \%$.

The highest infection was in male by two bacteria Bacillus spp (5 isolates) and Staphylococcus aureus (4 isolates) (Tables 3 and 4). Showed results Percentage of total bacteria isolated of female and male, were $38.46 \%$ and $61.53 \%$ respectively (Figure 2 ).

Table.1 Percentage of bacteria isolated from samples under nails

\begin{tabular}{|c|c|c|}
\hline Bacterial isolates (Species) & Number & Percentage \% \\
\hline Bacillus cereus & 2 & 7.69 \\
\hline Acinetobacter spp & 1 & 3.84 \\
\hline Bacillus spp & 7 & 26.92 \\
\hline Streptococcus spp & 1 & 3.84 \\
\hline Pseudomonas aeruginosa & 6 & 23.07 \\
\hline Staphylococcus aureus & 5 & 19.23 \\
\hline Klebsiella spp & 2 & 7.69 \\
\hline Unknow & 2 & 7.69 \\
\hline Total & 26 & $100 \%$ \\
\hline
\end{tabular}


Table.2 Morphological and biochemical characteristics of Bacterial isolates from under nails samples

\begin{tabular}{|c|c|c|c|c|c|c|c|c|c|c|c|}
\hline \multirow[t]{2}{*}{$\begin{array}{c}\text { Bacterial isolates } \\
\text { (Species) }\end{array}$} & \multirow[t]{2}{*}{$\begin{array}{l}\text { Gram } \\
\text { stain }\end{array}$} & \multirow[t]{2}{*}{ Shape } & \multirow[t]{2}{*}{$\begin{array}{l}* \\
\text { Ind. }\end{array}$} & \multirow[t]{2}{*}{ Oxid } & \multirow[t]{2}{*}{ Cata. } & \multirow[t]{2}{*}{ Cit. } & \multirow[t]{2}{*}{ Ure } & \multirow[t]{2}{*}{ Coag. } & \multirow[t]{2}{*}{ Nit. } & \multicolumn{2}{|c|}{$\begin{array}{c}\text { Sugar } \\
\text { fermentation }\end{array}$} \\
\hline & & & & & & & & & & Glucose & Lactose \\
\hline Bacillus cereus & + & Bacilli & -ve & -ve & $+\mathrm{ve}$ & $+\mathrm{ve}$ & -ve & -ve & $* * \mathrm{v}$ & $+\mathrm{ve}$ & -ve \\
\hline Acinetobacter spp & - & Bacilli & -ve & -ve & +ve & & $\mathrm{v}$. & -ve & $-\mathrm{ve}$ & $+\mathrm{ve}$ & $+\mathrm{ve}$ \\
\hline Bacillus spp & + & Bacilli & -ve & -ve & $+\mathrm{ve}$ & $+\mathrm{ve}$ & -ve & -ve & $+\mathrm{ve}$ & $+\mathrm{ve}$ & $\mathrm{v}$ \\
\hline Streptococcus spp & + & Cocci & -ve & -ve & -ve & -ve & -ve & -ve & -ve & $+\mathrm{ve}$ & $+\mathrm{ve}$ \\
\hline P. aeruginosa & - & Bacilli & -ve & $+\mathrm{ve}$ & $+\mathrm{ve}$ & $+\mathrm{ve}$ & $-\mathrm{ve}$ & $-\mathrm{ve}$ & $+\mathrm{ve}$ & -ve & -ve \\
\hline Staphy. aureus & + & Cocci & -ve & -ve & $+\mathrm{ve}$ & $+\mathrm{ve}$ & $+\mathrm{ve}$ & $+\mathrm{ve}$ & $+v e$ & $+\mathrm{ve}$ & $+\mathrm{ve}$ \\
\hline Klebsiella spp & - & Bacilli & -ve & -ve & $+\mathrm{ve}$ & $+\mathrm{ve}$ & $+\mathrm{ve}$ & -ve & $+v e$ & $+\mathrm{ve}$ & $+v e$ \\
\hline
\end{tabular}

* Ind: Indole Test, Oxid: Oxidase test, Cata: Catalase test, Cit: Citrate Utilization Test, Ure: Urease Test, Coag:

Coagulase Test and Nit: Nitrate reduction test, **V: Variable

Table.3 Bacteria isolated from under nails of female and male

\begin{tabular}{|c|c|c|}
\hline Bacterial isolates (Species) & female & male \\
\hline Bacillus cereus & 1 & 1 \\
\hline Acinetobacter spp & 0 & 1 \\
\hline Bacillus spp & 2 & 5 \\
\hline Streptococcus spp & 1 & 0 \\
\hline Pseudomonas aeruginosa & 3 & 3 \\
\hline Staphylococcus aureus & 1 & 4 \\
\hline Klebsiella spp & 2 & 0 \\
\hline Unknow & 0 & 2 \\
\hline Total & 10 & 16 \\
\hline
\end{tabular}

Table.4 Percentage of bacteria isolated from under nails of female and male

\begin{tabular}{|c|c|c|}
\hline \multirow{2}{*}{$\begin{array}{c}\text { Bacterial isolates } \\
\text { (Species) }\end{array}$} & \multicolumn{2}{|c|}{ Percentage \% } \\
\cline { 2 - 3 } & female & Male \\
\hline Bacillus cereus & 50 & 50 \\
\hline Acinetobacter spp & 0 & 100 \\
\hline Bacillus spp & 28.57 & 71.42 \\
\hline Streptococcus spp & 100 & 0 \\
\hline Pseudomonas aeruginosa & 50 & 50 \\
\hline Staphylococcus aureus & 20 & 80 \\
\hline Klebsiella spp & 100 & 0 \\
\hline Unknow & 0 & 100 \\
\hline
\end{tabular}


Fig.1 The percentage of Bacterial isolates from samples under nails

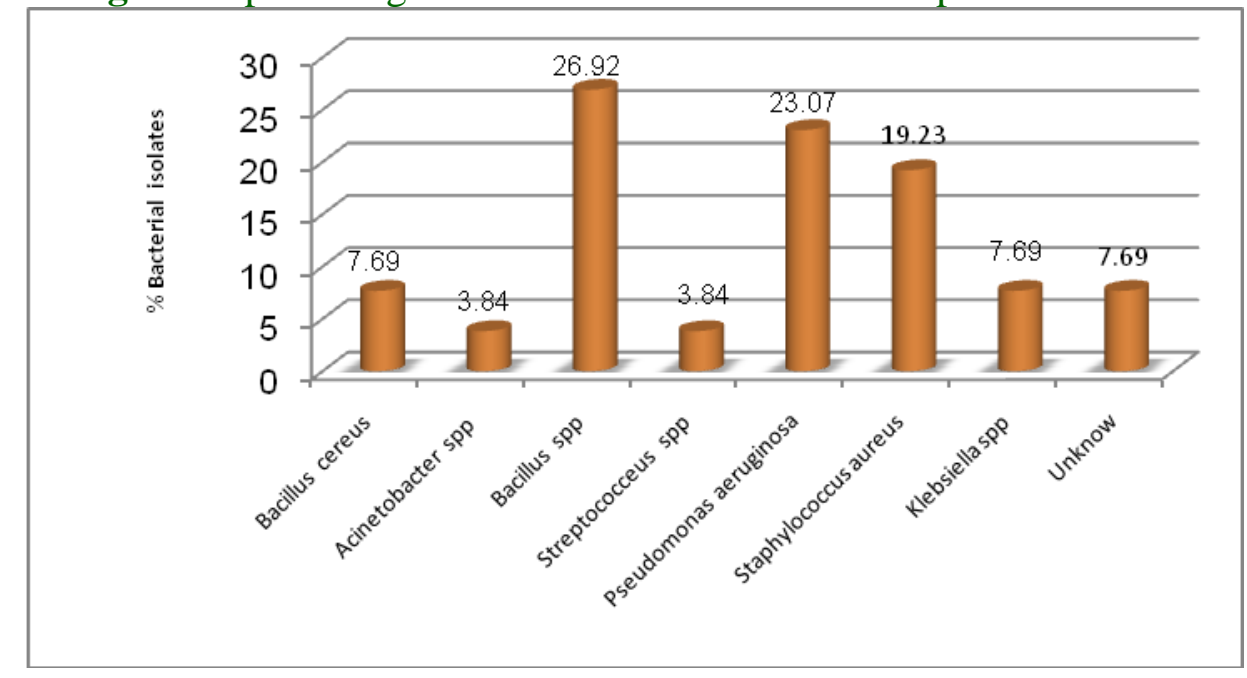

Fig.2 Percentage of total bacteria isolated from under nails of female and male

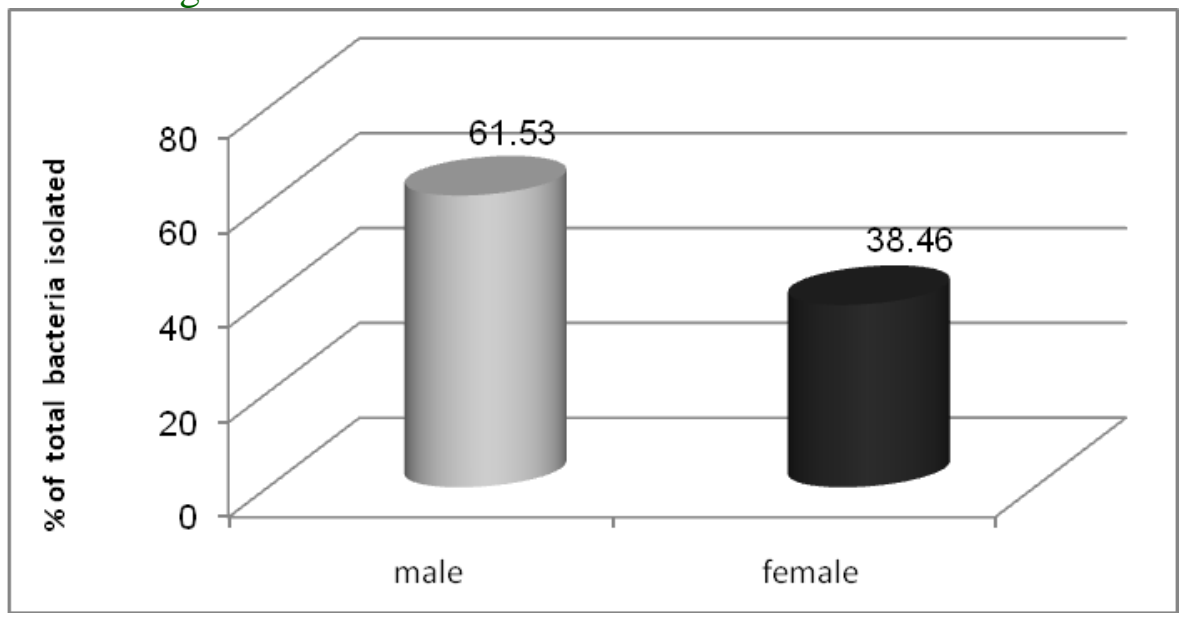

Rayan and Flournoy (1987) had reported heavy bacterial growth under fingernails that were more than $1 \mathrm{~mm}$ in length and showed that students with short finger nails (properly cut) had $64 \%$ bacterial contamination (bacterial count) and students with long finger nails showed more $(67 \%)$ contamination of bacterial count on their hands.

Lin et al., (2002) reported that long fingernail tends to harbors more microorganisms than short nails. Visibly clean nails were observed merely by appearance of finger nails of students, showed presence of $62 \%$ bacterial contamination on their hands. Ray et al., (2009) observed a decrease in colony count following hand washing with soap in $60 \%$ of the samples.

Tambekar et al., (2009) also observed highest bacterial contamination (70\%) was observed on the hands of the KG students followed by $67 \%$ on hands of primary students, $66 \%$ on secondary students, $64 \%$ on PG students and least $(57 \%)$ on the hands of under graduate students.

Ray et al., (2011) found that hand swab samples of $61 \%$ children harbours potential pathogens before taking food, also reported presence of pathogenic microbes on the hands of the students which included $S$. aureus, $E$. 
coli, Enterococcus faecalis, Klebsiella spp. Tambekar and Shirsat, (2012) reported the presence of E. coli, Pseudomonas spp., Proteus spp., Citrobacter spp., Klebsiella spp., Salmonella spp., Enterobacter spp. and $S$. aureus from the hand swabs of students. Chinakwe et al., (2012) also isolated E. coli, S. aureus, Enterobacter spp., Klebsiella spp., Enterococcus spp., Pseudomonas spp., Shigella spp. and Corynebacterium spp. from the hand-wash water samples. Oniya et al., (2006) isolated microorganisms transmissible through hand-shake and also reported prevalence of microorganisms was higher in primary and secondary school students than in the under graduate students. The reduction in the number of pathogens after hand washing was also reported by Tambekar et al., (2009).

\section{References}

Abdulkadir, M. and Waliyu S. (2012). Screening and Isolation of the Soil Bacteria for Ability to Produce Antibiotics, European Journal of Applied Sciences, 4, 211-215.

Akinyemi, K. O., Atapu A. D., Adetona, O. and Coker, A. O. (2009). The potential role of mobile phones in the spread of bacterial infections, J. Infect Dev Ctries; 3(8):628-632.

Bean, N. H., Goulding, J.S., Lao, C. and Angulo, F. J. (1996). Surveillance for foodborne disease outbreak, United States. Morbidity and Mortality Weekly Report, 45: 1-55.

Campbell, M. E., Gardner, C. E., Dwyer, J. J., Isaacs, S. M., Kruegger, P. D. and Ying J. Y. (1998). Effectiveness of public health interventions in food safety. A systematic review. Can. J. Public Health, 89: 197-202.

Chinakwe, E. C., Nwogwugwu, N. U., Nwachukwu I. N., Okorondu S. I., Onyemekara N. N., Ndubuisi-Nnaji U. U. (2012). Microbial quality and public health implications of hand-wash water samples of public adults in Owerri, South-East Nigeria. International Research Journal of Microbiology, 3(4): 144-146.

Ekrakene T. and Igeleke C. L. (2007). Microorganisms Associated with Public Mobile Phones along Benin-sapele Express Way, Benin City, Edo State of Nigeria. J. Appl. Sci. Res. 3(12):20092012.

Gupta R. S., (2012). Hand hygiene instruction decreases illness-related absenteeism in elementary schools: a prospective cohort study. BMC Pediatrics, 12:52.

Hedderwick S. A., McNeil S. A., Lyons M. J., Kauffman C. A. (2000) Pathogenic organisms associated with artificial fingernails worn by healthcare workers. Infect Control Hosp Epidemiol. 21(8):505-9.

Holding A. J. and Collee J. G., (1971) Routine biochemical tests, In Methods in Microbiology, (Norris JR and Ribbons DW, eds), Academic Press Inc. Ltd, London.,, pp 1-32.

Langford RM, 2009. Hand-washing and its impact on child health in Kathmandu, Nepal. Doctoral thesis, Durham University.

Lau C. H., Springston E. E., Sohn M., Mason I., Gadola E., Damitz M., Lin C., Wu F. M., Doyle M. P., Michaels B. S. and Williams K. (2002). Removal of Escherichia coli on hands with natural or artificial fingernails. International $J$. Epidemiol, 21: 1157-1164.

Oniya M. O., Obajuluwa S. E., Alade E. T. and Oyewole O. A. (2006). Evaluation of microorganisms transmissible through handshake. African $J$ Biotechnol, 5(11): 118-112.

Patel H. R., Daniel P. S., Anand I. S. and Patel C. N. (2010). Role of community pharmacist in assessing the awareness of hand hygiene in rural area. Journal of 
Global Pharma Technology, 2(5): 5961.

Prescott L. M; Harley J. P; Klein D. A (2005). Microbiology. 6th ed. Tim McGrawHill co. New Delhi. pp: 675.

Ramos J. L. (2004) Pseudomonas. New York: Kluwer Academic/Plenum Publishers; p. 2132.

Ray S. K., Amarchand R., Srikanth J. and Majumdar K. K. (2011). A study on prevalence of bacteria in the hands of children and their perception on hand washing in two schools of Bangalore and Kolkata. Indian Journal of Public Health, 55(4):293-297.

Ray S. K., Dobe M., Lahiri A. and Basu S. S. (2009). Hand washing practices in urban and rural communities in and around Kolkata, West Bengal. Indian J Public Health, 53:1192-1195.

Rayan G. and Flournoy D. (1987).
Microbiologic flora of human fingernails. The Journal of Hand Surgery, 12A: 605-607.

Tambekar D. H. and Shirsat S. D. (2012). Minimization of illness absenteeism in primary students using low-cost hygiene interventions. Journal of Health and Allied Sciences, 11(2):1-4.

Tambekar D. H., Shirsat S. D., Kakde S. R. and Ambekar K. B. (2009). Hand hygiene and health: An epidemiological study of students in Amravati. Afr $J$ Infect Dis, 3(1): 26-30.

Wachukwu, C. K., S. D. Abbey, A. O. Ollor and Obilor N. L. (2007). Public Health Implication of Artificial Finger Nails Used by Health Workers and Food Handlers in Port Harcourt, Nigeria. Journal of Applied Sciences, 7:35803583.

\section{How to cite this article:}

Mohsen Hashim Risan. 2017. Isolation and Identification of Bacteria from under Fingernails. Int.J.Curr.Microbiol.App.Sci. 6(8): 3584-3590. doi: https://doi.org/10.20546/ijcmas.2017.608.430 